Boise State University

ScholarWorks

Public Policy and Administration Faculty

Publications and Presentations

Department of Public Policy and Administration

$7-1-2018$

A Happy Combination?: Great Interests, Particular Interests, and State-Federal Conflicts Over Public Lands

John Freemuth

Boise State University

This is a pre-copyedited, author-produced PDF of an article accepted for publication in Publius following peer review. The version of record: Freemuth, J.(2018). A Happy Combination?: Great Interests, Particular Interests, and State-Federal Conflicts over Public Lands. Publius, 48(3), 454-468

is available online at doi:10.1093/publius/pjy008 


\title{
A Happy Combination?: Great Interests, Particular Interests, and State-Federal Conflicts Over Public Lands
}

\author{
John Freemuth \\ Boise State University \\ jfreemu@boisestate.edu
}

\begin{abstract}
This article analyzes recent developments regarding public lands and their management, focusing on state demands to gain control over federal lands and controversies over national monument designation and the legality of monument reductions. I place recent conflicts over public lands in historical context and show that they are, for the most part, nothing new. Since the 1890s, when the first forest reserves (now national forests) were established, there have been calls to transfer much of the federally-managed public lands to states for their management or sell them to private interests. There has also been a century-plus disagreement over naturalresources use versus protection of these same lands. I argue that these conflicts generally follow predictable patterns, while also noting several recent departures from historical patterns.
\end{abstract}

The federal Constitution forms a happy combination in this respect; the great and aggregate interests being referred to the national, the local and particular to the State legislatures.

Federalist 10

The federally managed public lands of the United States have received much attention recently. The occupation of the Malheur National Wildlife Refuge in Oregon by Ammon and Ryan Bundy and others in 2016, along with various court trials of the occupiers and the Bundys' father Cliven, brought public land policy back onto the public stage in a way not seen since the Sagebrush Rebellion of the 1970s. Much like the sagebrush rebels of the 1970s, the Bundys objected to the management of some of the western lands by the Bureau of Land Management (BLM), and called for state management of at least the BLM-managed part of the federal estate. The drama continued to build through the actions of President Donald Trump's Interior Secretary Ryan Zinke, who undertook an unprecedented review of national monuments proclaimed by Presidents Bill Clinton, George W. Bush and Barack Obama. Meanwhile, Zinke’s emphasis on extractive uses of the public lands (i.e., oil and gas development, coal leasing, forestry and grazing) suggests that the public land policy pendulum has swung yet again, this time towards use rather than preservation of these lands.

This article begins by offering a short history of the public lands and some of the important federal-state disagreements over public land policy and management, paying particular attention to the Antiquities Act. I then discuss recent developments regarding public lands and their management, including state demands to gain control over federal lands and controversies over national monument designation and the legality of monument reductions. One purpose of such an analysis to determine to what extent current conflicts over the public lands follow the usual ebb and flow of policy and to what extent recent developments mark a departures from historical patterns.

Viewed in one way, recent actions can be seen as merely the latest chapter in longstanding state-federal arguments and ideological disagreements about public lands and monuments. Once again, state legislatures are challenging federal land management and, as before, a Republican administration is more supportive of extractive use of public lands and a reduction in the size of monuments. However, unlike prior western protests about federal land management, recent protests are not responding to a particular federal statute or focusing event. Additionally, recent Trump administration actions and proposals regarding reducing monuments are more drastic than those considered by prior administrations and may finally force a legal resolution of certain issues about presidential power under the Antiquities Act that have not yet been fully resolved in court. 
This is an author-produced, peer-reviewed version of this article. The final, definitive version of this document can be found online at Publius, published by Oxford University Press. Copyright restrictions may apply. doi: 10.1093/publius/pjy008

For the purposes of this discussion, the term "federally managed public lands" refers to lands managed by the National Park Service, the Bureau of Land Management and the U.S Fish and Wildlife Service in the Department of the Interior, and the U.S. Forest Service in the Department of Agriculture. Today the four major federal land agencies manage about 27 percent of the total land mass of the United States (total mass is around 2,271,000,000 acres), much of it in the western part of the country. The U.S. Forest Service manages about 193 million acres, the National Park Service about 79 million acres, the Fish and Wildlife Service 89 million acres and the Bureau of Land Management 248 million acres. In the eleven western states, the federally-managed public lands constitute about 48 percent of total acreage (Vincent et al. 2017, 21). The BLM also manages the mineral estate beneath its own lands as well as well as those of the other federal agencies mentioned above. The BLM also manages 58 million acres of federal mineral estate beneath surface lands owned by non-Federal (state and private) entities, known as "split estate." In total, the BLM manages nearly 700 million acres of Federal sub-surface mineral estate across the nation. There are other federal lands, notably Department of Defense lands, but these are not considered in this article, as they raise different issues.

\section{A Brief History of the Federally Managed Public Lands}

U.S. land policy predates the founding of the United States itself, as both the British and the colonists, for example, regulated the cutting of forests to preserve a supply of timber for building naval vessels. After the Revolutionary War, the new American nation quickly sought both to acquire more land and to ensure private sector ownership through land disposal. These policies have been termed the Acquisition and Disposal phases of public land policy (Clawson 1983). Acquisition was accomplished by war or purchase. Disposal was enacted to raise revenue and promote new settlement. The native inhabitants of these lands were removed from much of the public lands, usually by force. These early policies shaped much of the thinking around land use in the U.S. and can be traced into the modern era, as disposing public land to private ownership remains attractive to certain people today.

The 1860s brought a new policy concerning federal land in the western U.S., a policy approach referred to as Reservation. This policy began in earnest in 1872 with the creation of Yellowstone National Park, the first national park in the U.S. and the world (Clawson 1983; Runte 1987). Reservation, simply understood, means that certain public lands would not be sold, but instead retained or reserved for public purposes. In the case of U.S. national parks, others would follow after Yellowstone, though in an ad hoc and piecemeal fashion for a time. The creation of Yellowstone was not a complete reversal of policy, however. The same year also saw the passage of the General Mining Act, an act designed to encourage mining and prospecting on most federal lands.

By the 1880s, there were also growing concerns over deforestation. Deforestation led Congress to give the President the power to create "forest reserves" in 1891. Renamed "national forests," they were transferred from the Department of Interior and placed under the administration of the U.S. Forest Service (USFS), which was created in 1905. Congress later took away that presidential power in 1907, but did provide for the creation of additional national forests in the East under the 1911 Weeks Act, which allowed for purchase of certain private lands in the East for conservation purposes.

Gifford Pinchot, first Chief of the USFS, helped make it the first professional land management agency in the U.S. Pinchot and others made clear that the forests were to be managed for the production of resources to be used by citizens. Pinchot offered a set of natural resource management "principles" to the American public. Those principles have been distilled as stressing that: 1 ) resources should be put to active use; 2) resource use should not be wasteful; and 3) resources should be used for the benefit of the many, not the few (Cawley 1998, 62). Pinchot's principles were the first clearly defined goals for forest management. The achievement of these goals could be accomplished through the science of forestry. As Pinchot $(1967,42)$ asserted: "The first great fact about conservation is that it stands for development. There has been a fundamental misconception that conservation means nothing but the husbanding of resources for future generations... Conservation does mean provision for the future, but it means also and first of all the recognition of the right of the present generation to the fullest necessary use of all the resources of which this country is so abundantly blessed. Conservation demands the welfare of this generation first and afterward the welfare of generations to follow."

Pinchot's philosophy had a blind spot, however. After an earthquake ravaged San Francisco in 1906, the city sought a reliable water source and turned to the Hetch Hetchy Valley in Yosemite National Park. This action precipitated a lengthy battle, pitting Pinchot against his former friend John Muir, and putting President Theodore Roosevelt in the middle. The Hetch Hetchy dam was built and the National Park Service (NPS) created in 1916 to make sure such an 
This is an author-produced, peer-reviewed version of this article. The final, definitive version of this document can be found online at Publius, published by Oxford University Press. Copyright restrictions may apply. doi: 10.1093/publius/pjy008

incursion would not happen again and with a charge to manage and conserve parks and provide "enjoyment for future generations" (Runte 1987). Ironically, had Pinchot seen more value in national parks, perhaps the National Park Service would not have been established (Fox 1981).

The creation of the national forest system was not uniformly popular. As early as 1912, the Chief of the Forest Service William Graves noted a federalism-based quarrel about the national forests:

These are public resources which should be handled in the interests of the public. Moreover, the problems involved are such that they should definitely remain in the hands of the National rather than be turned over to the State governments. The property belongs to the Nation as a whole, and every citizen has an interest in it.... The underlying purpose of the proposed transfer of the national forests to the States is really not to substitute State for Federal control, but rather to substitute individual for public control. Its most earnest advocates are the very interests which wish to secure such control... The proposition is one which the people as a whole would repudiate in an instant if they understood what is proposed. (Dana 1956, 179, emphasis added)

Debates about who could best manage the federal land estate are therefore hardly new and date back well over a century. President Theodore Roosevelt (who, like presidents before him, had created several national forest reserves) also used his authority to create the first national wildlife refuges, including Malheur, which were separate from national forests. Other presidents would follow his lead, as would Congress. Such early reserves and those that followed would be managed by the U.S. Fish and Wildlife Service (USFWS), created in 1940 after many earlier, lesscoordinated arrangements. USFWS lands were set aside specifically to preserve land for wildlife habitat. In addition to creating the nation's first national wildlife refuges, Roosevelt made extensive use of the Antiquities Act of 1906, as discussed in more detail below. The policy of public land retention and reservation evolved into a new era of federal land management. Over time, various federal agencies would be delegated powers by Congress to manage the federal land estate.

The Bureau of Land Management (BLM) receives more attention today than the other land management bureaus regarding policy approaches to management. BLM was created in 1946 out of a merger of the old General Land Office and the Grazing Service, which had been created by the Taylor Grazing Act in 1934. The Taylor Grazing Act was passed to manage and regulate western livestock grazing and to help reduce overgrazing. One key phrase of that act stated: "That in order to promote the highest use of the public lands pending its final disposal, the Secretary of the Interior is authorized, in his discretion, by order to establish grazing districts” (43 USC Section 315).

A few years before the Taylor Grazing Act was passed, federal officials, including Secretary of Interior Ray Lyman Wilbur and President Herbert Hoover, offered to transfer the pre-BLM public lands minus the sub-surface mineral estate to the states to manage. The states, however, declined, citing the poor condition of the surface estate. But the word "disposal" in the Taylor Grazing Act led some to conclude then (and continue to conclude to this day) that eventually these public lands would be transferred to the states to manage — or perhaps be sold by the state in question.

The BLM was dominated by and generally conformed to the desires of western congressmen and their rancher and mining constituencies, leading scholars such as Phillip O. Foss to refer it as a "private government" or claim that the agency had been "captured" by the interests it was supposed to regulate. The BLM was sometimes referred to as the "Bureau of Livestock and Mining," as those were the primary commercial uses and users of these lands. Often, BLM employees came (and still come) from smaller western towns and ranch backgrounds and had been primarily trained at western land grant universities, reinforcing the tradition of placing a priority on using federal lands for their natural resources. Viewed as a western agency, the BLM catered to local and particularized interests during this time period, and in way that helps one understand, though not condone, the actions of contemporary protestors who believe western lands managed by BLM belonged to people like themselves.

The passage of the Federal Land Policy Act of 1976 (FLPMA) superseded the Taylor Grazing Act and made it national policy that the BLM lands would be retained in federal ownership. FLPMA stated that the BLM lands should be managed: "In a manner that will protect the quality of scientific, scenic, historical, ecological, environmental, air and atmospheric, water resource, and archeological values; that, where appropriate, will preserve and protect certain public lands in their natural condition; that will provide food and habitat for fish and wildlife and domestic animals; and that will provide for outdoor recreation and human occupancy and use” (Pub. L. No. 94-579, Section 102(a) (8)). 
This is an author-produced, peer-reviewed version of this article. The final, definitive version of this document can be found online at Publius, published by Oxford University Press. Copyright restrictions may apply. doi: 10.1093/publius/pjy008

FLPMA's passage, in combination with other new environmental laws and growing public interest in non-commercial purposes such as recreation, wildlife and wilderness, ignited the Sagebrush Rebellion of the late 1970s. There had been previous protests dating back to the creation of forest reserves early in the 20th century; but this 1970s rebellion brought new attention to federal land management, primarily BLM-managed lands. As noted above, observers such as Foss had explained that the BLM was a "captured agency," overseen by the very resource users it was supposed to regulate, in this case primarily ranchers and the mining industry and with support from western congressmen. Now, the "capture" appeared over. BLM was slated to manage for multiple uses, much like the Forest Service, and that meant users and uses beyond grazing and mining. Perhaps worse, in the perceptions of traditional users, the implementation of FLPMA was to be undertaken by President Jimmy Carter and his Secretary of Interior Cecil Andrus, men with significant environmental credentials.

For a time in the late 1970s, states such as Nevada acted by passing legislation claiming "moral and legal claims" on the lands managed by BLM. (Cawley 1993, 95). There was also an effort in Congress by Senator Orrin Hatch (R-UT) and others to pass legislation setting up a process for convening BLM and Forest Service lands to states (Cawley 1993, 101). Ronald Reagan's election in 1980 helped defuse the Sagebrush Rebellion movement, as his Secretary of the Interior James Watt pushed for the restoration of traditional natural resource uses and the weakening of environmental regulations (Cawley 1993). Still, the BLM continues to manage much of its land for the use of natural resources, as does the USFS; but these bureaus now include preservation as an equally important objective.

\section{History and Development of the Antiquities Act}

The Antiquities Act was adopted in 1906, originally to conserve the stunning archaeological treasures of the American Southwest. As settlers, prospectors, ranchers, and explorers entered the region in the late 1800s, they discovered unique and spectacular sites left by Anasazi, ancestral Pueblo people who lived in the area from about A.D. 700 to 1600. Sites that readers might be familiar with include dwellings such as the Cliff Palace and Spruce Tree House in what is now Mesa Verde National Park in Colorado. These discoveries also led to pot hunting, looting, and even shipping artifacts to institutions and universities in the east and abroad. Concerned scholars and scientists began to call for controls. J. Walter Fewkes, a prominent archaeologist, warned in 1896 that unless this plundering of ancient sites was curbed, "many of the most interesting monuments of the prehistoric peoples of our Southwest will be little more than mounds of debris at the bases of the cliffs" (quoted in Lee 2006, 24).

Spurred on by further vandalism and looting, Congress took action. With essential staff leadership by a young archeologist, Edgar Lee Hewett, and the sponsorship of Representative John Lacey (R-IA), Congress passed the Antiquities Act. The law's key provision states: "That the President of the United States is hereby authorized, in his discretion, to declare by public proclamation historic landmarks, historic and prehistoric structures, and other objects of historic or scientific interest that are situated upon the lands owned or controlled by the Government of the United States to be national monuments, and may reserve as a part thereof parcels of land, the limits of which in all cases shall be confined to the smallest area compatible with proper care and management of the objects to be protected" (Act for the Preservation of American Antiquities, Pub. L. No. 59-209).

President Theodore Roosevelt took a number of aggressive executive actions to protect public lands and wildlife, relying in part on the Antiquities Act. In one case, he used the new Antiquities Act to set aside over 800,000 acres of the Grand Canyon, which was later designated as a national park with expanded boundaries by Congress. When his action was challenged in the case of Cameron v. United States, 252 U.S. 450 (1920), for violating the Act's clause confining monuments to "the smallest area compatible with proper care and management of the objects to be protected," the U.S. Supreme Court sustained his decision. The Court ruled that President Roosevelt had a broad grant of power to, in the words of the Act, establish reserves embracing "objects of historic or scientific interest," and thereby declare, as Roosevelt stated in his proclamation, that the Grand Canyon "is an object of unusual scientific interest." Additionally, the Court did not consider the size of the monument within the proclamation to be too large. This ruling can be viewed as opening the door to other large monuments. Those monuments would later become familiar national parks such as Olympic, Zion, Bryce, Arches, Death Valley, and Joshua Tree.

Use of the Antiquities Act has fueled tensions between the federal government and states over land control, and not just in the Southwest region that the law was originally intended to protect. Communities have opposed creating new monuments for fear of losing revenues from livestock grazing, energy development, or other activities, although such uses have been allowed to continue at many national monuments. 
This is an author-produced, peer-reviewed version of this article. The final, definitive version of this document can be found online at Publius, published by Oxford University Press. Copyright restrictions may apply. doi: 10.1093/publius/pjy008

In the 1930s Wyoming residents objected when John D. Rockefeller offered to donate land that he owned near Jackson Hole to enlarge the original Grand Teton National Park. When Rockefeller threatened to sell the property instead, President Franklin Roosevelt combined the land with 179,000 acres from Grand Teton National Forest to create a national monument in 1943, which later was added to the national park. Wyoming Republican Senator Edward Robertson called the step a "foul, sneaking Pearl Harbor blow" (quoted in Rothman 2006, 83). In 1950 Congress amended the Antiquities Act to require congressional approval for any future monuments designated in Wyoming.

The next controversy flared in 1978 when President Jimmy Carter, acting on advice from Interior Secretary Cecil Andrus, designated seventeen national monuments in Alaska totaling more than 50 million acres. Carter took this step in part after one of Alaska's senators, Mike Gravel, delayed action and threatened to filibuster pending legislation to create national parks, national forests and wildlife refuges on these lands. Alaskans protested, but in 1980 Congress passed compromise legislation that converted the lands to parks and refuges. Once again, Congress amended the Antiquities Act to require congressional approval for any future national monuments larger than 5,000 acres in Alaska.

In 1996 President Bill Clinton designated the Grand Staircase-Escalante National Monument in Utah, a spectacular swath of red rock canyons and mesas in the Colorado Plateau. Clinton administration officials sought to protect the areas from proposed coal mining nearby. The Interior Department tried to soften local opposition by offering Utah access to coal resources elsewhere through land exchanges. But Clinton proclaimed the monument without much advance consultation with local communities, leaving some Utahans feeling blindsided and resentful years later.

\section{Recent State Challenges to Federal Management of Public Lands}

In recent years, officials, groups, and individuals in several states have launched various challenges to federal ownership of public lands. These actions in the 2010s can be seen in one sense as resembling state actions during prior state-federal controversies such as the Sagebrush Rebellion in the 1970s. What is different this time is that, unlike every other western protest about federal lands management, there was not a focusing event like FLPMA to mobilize Westerners. Moreover, some of the ideas seem to have come from non-westerners (ALEC 2013).

In 2012, the argument over the best level of government to manage part or all of the federal land estate resurfaced in Utah and Arizona. ${ }^{1}$ In March 2012, the Arizona legislature passed a bill that called for federal land agencies to give up title to roughly 48,000 square miles (124,000 square kilometers) of federal land by 2015 . Arizona governor Jan Brewer vetoed the bill for reasons including cost and legal uncertainties. The Arizona legislature then placed on the ballot Proposition 120, a state constitutional amendment calling for the federal government to relinquish what would amount to most non-Native American land within the state, including Grand Canyon National Park. The proposition stated that Arizona "Declares its sovereign and exclusive authority and jurisdiction over the air, water, public lands, minerals, wildlife and other natural resources within its boundaries” (Arizona Secretary of State 2012a). Only established Native reservations, plus a trivial amount of state cessations and small military reservations were not included. Voters overwhelmingly defeated the proposition in November 2012, voting it down by a two-one margin (Arizona Secretary of State 2012b, 18). This is, as far as is known, the only recent referendum on federal land ownership.

The Utah legislature in 2012 passed the "Transfer of Public Lands Act and Related Study." The law required the United States to extinguish title to public lands and transfer title to those public lands to the state on or before December 31, 2014 (Utah 2012, 79). The law also commissioned a study by Utah's Constitutional Defense Council to be presented to the 2013 general session of the legislature. The governing assumption of the report prepared by the Council and Utah's Public Lands Policy Coordinating Office was that "those closest to, and whose lives are most directly impacted by, these public lands are better situated to make decisions regarding the use and enjoyment of these lands" (Utah 2012, 4). Nevertheless, the authors of the report acknowledged that they were dealing with a complicated issue, as demonstrated by statements to the effect that a transfer of federal lands "will require a reexamination of public lands policy on a federal, state and county level" and that any such action "must be fully informed and its implications thoughtfully evaluated” (Utah 2012, 79).

\footnotetext{
${ }^{1}$ This discussion draws on Freemuth 2014, 2018.
} 
This is an author-produced, peer-reviewed version of this article. The final, definitive version of this document can be found online at Publius, published by Oxford University Press. Copyright restrictions may apply. doi: 10.1093/publius/pjy008

After the December 2014 deadline passed without any action on the part of federal officials, Utah legislators turned to consider litigation. In December 2015, the Utah Commission for the Stewardship of Public Lands reviewed a report prepared by outside lawyers setting out legal options for challenging federal ownership of 31 million acres of public lands in the state (Legal Consulting Services Team 2015). The commission voted to direct outside counsel to prepare a complaint, albeit with the proviso that the state attorney general would make the final decision on whether to actually file a lawsuit (Maffly 2015). Then, in March 2016 the Utah legislature authorized \$4.5 million in state funds to finance work on this potential lawsuit (Gerhke 2016). As of this writing, no lawsuit has been filed, whether for the purpose of forcing the federal government to transfer title of the public lands to the state or challenging the legitimacy of the provision of the 1976 FLPMA that calls for retention of federal ownership of public lands. In early 2018, the Utah attorney general indicated that if any such suit were filed, it would likely focus on testing the legitimacy of relevant provisions of the FLPMA (Maffly 2018).

Most legal and other scholars do not view legal action to force the federal government to turn over public lands to the states as having any chance of succeeding, because the authority to manage or dispose of public lands derives from the Property Clause of the U.S. Constitution: "The Congress shall have Power to dispose of and make all needful Rules and Regulations respecting the Territory or other Property belonging to the United States; and nothing in this Constitution shall be so construed as to Prejudice any Claims of the United States, or of any particular State" (Article IV, Section 3 clause 2). Idaho Attorney General Lawrence Wadsen answered the legal question definitively and succinctly when he said recently that "My office undertook an extensive analysis of ... the legal history of federal land ownership -- and concluded that there was no legal basis for a court action seeking to force the United States to turn these lands over to the state. But we encouraged the legislature to take their concerns to Congress because ultimately, the power to transfer public lands to Idaho resides in Congress, not in the courts" (quoted in Andrus Center for Public Policy 2017, emphasis added). Wadsen's point that any federal land transfer requires congressional action is commonly accepted by scholars. (see also Leshy, 2018).

\section{Recent Conflicts About National Monuments}

President Trump issued an Executive Order on April 26, 2017 directing Interior Secretary Zinke to initiate a review of certain national monuments designated by past presidents under the Antiquities Act. The order had several review standards, including a review of the size of certain monuments created by presidential proclamation. The order states that the: "Secretary of the Interior (Secretary) shall conduct a review of all Presidential designations or expansions of designations under the Antiquities Act made since January 1, 1996, where the designation covers more than 100,000 acres, where the designation after expansion covers more than 100,000 acres, or where the Secretary determines that the designation or expansion was made without adequate public outreach and coordination with relevant stakeholders... to determine whether each designation or expansion conforms to the policy set forth in section 1 of this order" (emphasis added). The executive order also set out several considerations to guide the Secretary's determination. First, the review should consider "the requirements and original objectives of the Act, including the Act's requirement that reservations of land not exceed 'the smallest area compatible with the proper care and management of the objects to be protected"" (emphasis added). Second, the review should consider "whether designated lands are appropriately classified under the Act as 'historic landmarks, historic and prehistoric structures, [or] other objects of historic or scientific interest'” (Presidential Executive Order on the Review of Designations under the Antiquities Act 2017, emphasis added).

Pursuant to this executive order, Interior Secretary Zinke reviewed twenty-seven national monuments established during the Clinton, Bush, and Obama administrations and then submitted a draft report to the president on August 24, 2017 and released a final report on December 5, 2017 (United States Secretary of the Interior 2017). In summarizing his recommendations, Zinke advised the president to use his "discretion to modify certain existing proclamations and boundaries," by continuing "to identify particular objects or sites of historic or scientific interest and recite grounds for the designation thereby comporting with the Act's policies and requirements," but doing so "in a manner that prioritizes public access, infrastructure, traditional use, tribal cultural use, and hunting and fishing rights" (United States Secretary of the Interior 2017, 9-10). Zinke recommended reductions in the boundaries of four monuments: Bears Ears National Monument and Grand Staircase-Escalante National Monument in Utah, Gold Butte National Monument in Nevada, and Cascade-Siskiyou National Monument in Oregon. He also recommended changes in the proclamations and management plans for six other national monuments but without recommending any changes in their boundaries. 
This is an author-produced, peer-reviewed version of this article. The final, definitive version of this document can be found online at Publius, published by Oxford University Press. Copyright restrictions may apply. doi: 10.1093/publius/pjy008

Zinke's final report was released a day after President Trump on December 4, 2017 issued proclamations reducing the size of two national monuments featured in Zinke's report, both in Utah. Bears Ears National Monument, proclaimed by President Obama in 2016, was reduced from 1.3 million acres to 228,000 acres. Grand Staircase-Escalante National Monument, designated by President Clinton in 1996, was cut nearly in half, from its nearly 1.9 million acres to about 1 million acres (National Public Radio 2017). To date, these are the only two actions that the Trump administration has taken to reduce the size of any national monuments.

In the days after Trump's December 4, 2017 proclamations, a wide range of groups filed lawsuits in the U.S. District Court for the District of Columbia. Challengers included Native American tribes, environmental protection and conservation groups, historic preservation groups, paleontologists, and the outdoor clothing company Patagonia. Three lawsuits target the reduction in the size of Bears Ears National Monument; two more lawsuits challenge the shrinking of Grand Staircase-Escalante National Monument (Tanner 2017). Plaintiffs advance a number of legal claims. Their principal argument, which has not been resolved by federal courts and is likely to finally be addressed in these cases, is that presidents lack the authority to eliminate or reduce the size of a national monument after its creation.

In considering the legal justification for Trump's actions and the strength of the legal challenges, scholars have looked at the record of prior presidential efforts to abolish or reduce the size of monuments. In 1938, President Franklin Roosevelt considered abolishing the Castle-Pinckney National Monument in South Carolina. Attorney General Homer Cummings was asked to rule on whether the president could do this and concluded Roosevelt could not abolish the monument. He argued: "The statute does not in terms authorize the President to abolish national monuments, and no other statute containing such authority has been suggested. If the President has such authority, therefore, it exists by implication.” He also concluded that the President did not have implied authority to abolish national monuments. Roosevelt did not attempt to abolish Castle-Pinkney National Monument; but Congress abolished the monument later in 1951 (Wyatt 2016).

Further context for these legal issues is found in the 1976 FLPMA, which expressly prohibits the Secretary of the Interior from modifying or revoking any withdrawal creating national monuments under the Antiquities Act, a provision that makes it clear that president cannot delegate the power to revoke a monument to an administrative official. More interestingly, House Report 94-1163, which accompanied FLPMA, appears to signal that the prohibition may also apply to the president. This provision came with the House bill, H.R. 13777, as introduced and as reported by the 94th Congress. The committee report stated: "[The bill] would also specifically reserve to the Congress the authority to modify and revoke withdrawals for national monuments created under the Antiquities Act.... These provisions will insure that the integrity of the great national resource management systems will remain under the control of the Congress" (Wyatt 2016). One interpretation of this House report would suggest that Congress reserved the revocation power in terms of national monuments to itself.

In addition, it is worth noting that Congress has designated, expanded, modified boundaries of, and approved funding for many national monuments, further complicating the legality of any effort by the President to rescind monuments. For example, Craters of the Moon National Park and Preserve was on Trump's Executive Order review list with a reported 737,000 acres. This figure was incorrect for a number of reasons. First, it ignored the fact that the original Craters of the Moon National monument was proclaimed by President Coolidge in 1926 at around 22,000 acres. There were a number of subsequent adjustments, with the largest coming with President Clinton's addition of some 660,000 acres for both the Park Service and BLM to manage. But the list's acreage ignores the fact that Congress moved 410,000 aces of the NPS lands into a National Preserve. This puts all but 250,000 acres off limit to repeal by President Trump.

Can a president alter the boundaries of a national monument proclaimed by a predecessor? The answer is a tentative yes, because it has been done twelve times between 1911 and 1960, but not since the passage of FLPMA in 1976 and the language in the House Report (Vincent and Hanson 2017, 8). An interesting example involves Mount Olympus National Monument (now Olympic National Park), then under the management of the Forest Service, whose acreage was reduced by 313,280 acres by President Woodrow Wilson to make Sitka spruce available for fighting World War I. However, the pertinent issue today links to the phrase in the Antiquities Act that calls for a monument to be "confined to the smallest area compatible with proper care and management of the objects to be protected," as this phrase is also used in President Trump's Executive Order calling for a review. A drastic reduction in size that did not have a justification linked to this language would likely be viewed as an indirect attempt to gut the monument itself and be considered legally suspect. 
This is an author-produced, peer-reviewed version of this article. The final, definitive version of this document can be found online at Publius, published by Oxford University Press. Copyright restrictions may apply. doi: 10.1093/publius/pjy008

\section{Conclusion}

In one sense the policies that have emerged from the Trump administration follow a familiar pattern. The swing towards resource development has occurred again, as it did with the Reagan administration and two Bush Administrations. Yet, in other ways the changes undertaken by the Trump administration have accelerated and become more confrontational. In particular, Secretary Zinke's and President Trump's systematic alteration of two national monuments in Utah is unparalleled and is now under litigation. This recent conflict over the Antiquities Act illustrates how battles over the public lands have often been deep, long, and passionate; and they are unlikely to abate in the future. There are too many diverse public values, often in conflict with other values, to think otherwise.

In another respect, recent developments are notable because they may finally bring about a judicial resolution of longstanding legal questions. Although scholars have not viewed as in any way promising legal efforts to force transfer of ownership of public lands to the states, questions surrounding the legality of presidential reductions in the size of national monuments raise issues that have not been fully tested in court. In reducing dramatically the boundaries of two national monuments, the Trump administration has generated a host of legal challenges that seem destined to provide some judicial resolution to questions concerning the extent and limits of presidential power to alter monument proclamations of their predecessors.

\section{References}

American Legislative Exchange Council. 2013. Resolution Demanding that Congress Convey Title of Federal Public Lands to the States. January 28. https://www.alec.org/model-policy/resolution-demanding-thatcongress-convey-title-of-federal-public-lands-to-the-states/ (accessed January 29, 2014).

Andrus Center for Public Policy. 2017. Why Public Lands Matter. White Paper. https://sps.boisestate.edu/andruscenter/files/2018/01/WPLM-White-Paper-FINAL.pdf

Arizona Secretary of State. 2012a. Arizona’s General Election Guide: Proposition 120 http://apps.azsos.gov/election/2012/info/PubPamphlet/english/Prop120.htm (Accessed January 23, 2013).

Arizona Secretary of State. 2012b. Official Canvas - 2012 General Election. http://apps.azsos.gov/election/2012/General/Canvass2012GE.pdf

Cawley, R. McGreggor. 1993. Federal Land, Western Anger: The Sagebrush Rebellion and Environmental Politics. Lawrence: University of Kansas Press.

Cawley, R. McGreggor. 1998. We May Help to Make up the General Mind: Reuniting Wilson, Taylor, and Pinchot. Administrative Theory and Praxis 20 (1):55-67.

Clawson, Marion. 1983. The federal lands revisited. Baltimore, MD: Johns Hopkins University Press

Dana, Samuel Trask. 1956. Forest and Range Policy: Its Development in the United States. New York: McGrawHill.

Foss, Phillip O. 1960. Politics and Grass: The Administration of Grazing on the Public Domain. Seattle: University of Washington Press.

Fox, Stephen 1981. The American Conservation Movement: John Muir and His Legacy. New York: Little, Brown

Freemuth, John. 2014. The Progressive Movement and Conservation (1890s - present). In Guide to U.S. Environmental Policy, eds. Sally K. Fairfax and Edmund Russell. Washington, D.C.: Sage/CQ Press: 129140.

Freemuth, John. 2018. U.S. Public Lands and a New Administration: New and Old Issues. In Environmental Policy and the Pursuit of Sustainability, eds. Chelsea Schelly and Aparajita Banerjee: New York: Routledge.

Gehrke, Robert. 2016. Legislature Creates Fund for \$14 million public lands lawsuit. Salt Lake Tribune. March 10. http://archive.sltrib.com/article.php?id=3644622\&itype=CMSID

Lee, Ronald F. 2006. The Origins of the Antiquities Act. In The Antiquities: A Century of American Archaeology, Historic Preservation, and Nature Conservation, eds. David Harmon, Francis P. McManamon, and Dwight T. Pitcaithley: 15-34. Tucson: University of Arizona Press.

Legal Consulting Services Team. 2015. Legal Analysis Prepared for the Utah Commission for the Stewardship of Public Lands. Davillier Law Group. December 9. https://www.justice.gov/usao-or/file/851711/download

Leshy, John.2018. Are U.S. Public Lands Unconstitutional? Hastings Law Journal Vol. 69:499.

Maffly, Brian. 2015. Republicans OK \$14 million land-transfer lawsuit, say Utah must regain sovereignty. Salt Lake Tribune, December 9. http://archive.sltrib.com/article.php?id=3287281\&itype=CMSID 
This is an author-produced, peer-reviewed version of this article. The final, definitive version of this document can be found online at Publius, published by Oxford University Press. Copyright restrictions may apply. doi: 10.1093/publius/pjy008

Maffly, Brian. 2018. Utah Attorney General Sean Reyes hints at suing feds over control of public lands. Salt Lake Tribune, February 21. https://www.sltrib.com/news/environment/2018/02/21/utah-attorney-general-seanreyes-hints-at-suing-feds-over-control-of-public-lands/

National Public Radio. 2017. Trump Orders Largest National Monument Reduction In U.S. History. December 4. https://www.npr.org/sections/thetwo-way/2017/12/04/567803476/trump-dramatically-shrinks-2-utahnational-monuments (accessed February 13, 2018).

Nelson, Robert 1995. Public Lands and Private Rights: The Failure of Scientific Management. Lanham, MD: Rowman \& Littlefield.

Nelson, Robert. 2012. Our Languishing Public Lands. Policy Review, February 1. https://www.hoover.org/research/our-languishing-public-lands (accessed January 29, 2013).

Nelson, Robert 2014. Taking an Ax to Traditional Forest Management: The Charter School Approach Works for Education, So Why Not Apply It Elsewhere. Wall Street Journal. January 2.

Presidential Executive Order on the Review of Designations under the Antiquities Act 2017. https://www.whitehouse.gov/the-press-office/2017/04/26/presidential-executive-order-reviewdesignationsunder-antiquities-act (Accessed November 16, 2017).

Pinchot, Gifford. 1967. The Fight for Conservation. Seattle: University of Washington Press.

Rothman, Hal. 2006. Showdown at Jackson Hole: A Monumental Backlash against the Antiquities Act. In The Antiquities: A Century of American Archaeology, Historic Preservation, and Nature Conservation, eds. David Harmon, Francis P. McManamon, and Dwight T. Pitcaithley: 81-92. Tucson: University of Arizona Press.

Runte, Alfred. 1987. National Parks: The American Experience, 2nd ed. Lincoln: University of Nebraska Press.

Tanner, Courtney. 2017. Here's a breakdown of the 5 lawsuits filed against Trump that challenge his cuts to 2 Utah national monuments. Salt Lake Tribune. December 10. https://www.sltrib.com/news/politics/2017/12/11/heres-a-breakdown-of-the-5-lawsuits-filed-against-trumpchallenging-his-cuts-to-two-utah-national-monuments/ (Accessed February 26, 2018)

United States Forest Service. 2002. The Process Predicament: How Statutory, Regulatory, and Administrative Factors Affect National Forest Management. June. https://www.fs.fed.us/projects/documents/ProcessPredicament.pdf

United States Secretary of the Interior. 2017. Final Report Summarizing Findings of the Review of Designations under the Antiquities Act. December 5. https://www.doi.gov/sites/doi.gov/files/uploads/revised_final_report.pdf

Utah. 2012. Report on Utah’s Transfer of Public Lands Act HB 148. November 14. http://digitallibrary.utah.gov/awweb/awarchive?type=file\&item $=73645$

Vincent, Carol Hardy, Laura A. Hanson, and Carla N. Argueta. 2017. Federal Land Ownership: Overview and Data. Congressional Research Service. March 3. https://fas.org/sgp/crs/misc/R42346.pdf

Vincent, Carol Hardy, and Laura A. Hanson. 2017. Executive Order for Review of National Monuments: Background and Data. Congressional Research Service. October 18. https://fas.org/sgp/crs/misc/R44988.pdf

Wyatt, Alexandra. 2016. Antiquities Act: Scope of Authority for Modification of National Monuments. Congressional Research Service. November 14. 